\title{
Evaluation of anti-cancer effects of root and beet leaf extracts (Beta vulgaris L.) in cervical cancer cells
}

\section{Stefhani A. Romero*, Isadora C. B. Pavan, Ana Paula Morelli, Luiz Guilherme S. da Silva, Isabella Fagundes, Cayo H. R. Silva, Rosângela M. N. Bezerra, Fernando M. Simabuco.}

\section{Abstract}

Cervical cancer is the third cause of cancer between women in 2018. Beetroot has bioactive compounds that have the ability to inhibit the progression of different types of cancer cells. The present study analyzed the possible functional effects of leaf and root extracts of beet as anti-tumor agents in cultures of HeLa cervical cancer cells, testing viability (MTT) and colony formation. The results showed a reduction in viability at concentrations of 10 and $100 \mathrm{ppm}$ and in the diameter of the colonies at the concentration of $10 \mathrm{ppm}$. This work may contribute for new therapeutic and adjuvant approaches for cervical cancer treatment using beet derived compounds and extracts.

Key words: Cervical cancer, apigenin, beet.

\section{Introduction}

Cancer was described as the cause of about 9.2 million deaths worldwide in $2018^{1}$ and represents in Brazil the second largest cause of death. Among the cancers, cervical cancer is ranked third with $8.1 \%$ incidence among cancer cases that affect women in $2018^{2}$. Beetroot contains in its composition bioactive compounds capable of inhibiting the advance of different types of cancer cells, such as apigenin and its derivatives, through the regulation of the cell cycle, decrease in the growth and induction of apoptosis in some cell lines ${ }^{34}$. The present study analyzed the possible functional effects of extracts of leaves and roots of beet and apigenin as antitumor agents in cultures of HeLa cervical cancer cells.

\section{Results and Discussion}

The results demonstrated decreased cell viability of cervical cancer cells (HeLa) when treated with leaf and beet root extracts. The reduction was evidenced in the concentrations of 10ppm and 100ppm (A and B). The viability after treatment with extracts at $10 \mathrm{ppm}$ combined with anti-cancer drugs rapamycin and cisplatin was also analyzed, obtaining a greater decrease in viability in the combined extracts compared to cells treated only with the drugs ( $C$ and $D)$. In the analysis of colony formation (Figure 2), the cells treated with concentrations of 1 and $10 \mathrm{ppm}$ did not present a statistical difference regarding quantity, but a difference in the diameter of the colonies was observed, demonstrating the decrease of the proliferation.

Figure 1. Cell viability analysis (MTT; $n=3$ ); the bars represent the mean \pm SEM. Means significantly different as shown by One-Way Anova, post test Turkey vs. control ( ${ }^{*} p<0,05$; ${ }^{* *}$ $\left.p<0,01 ;{ }^{* \star *} p<0,001 ;{ }^{\star * \star *} p<0001\right)$. All treatments in figure $1 \mathrm{C}$ and 1D decreased compared to control, except Cisplatin for 24 hours.
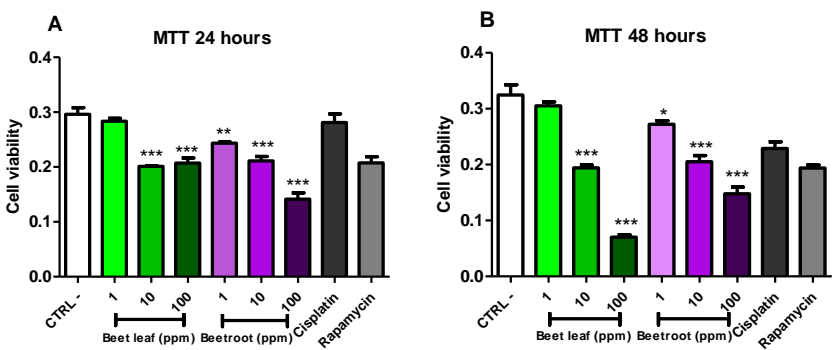
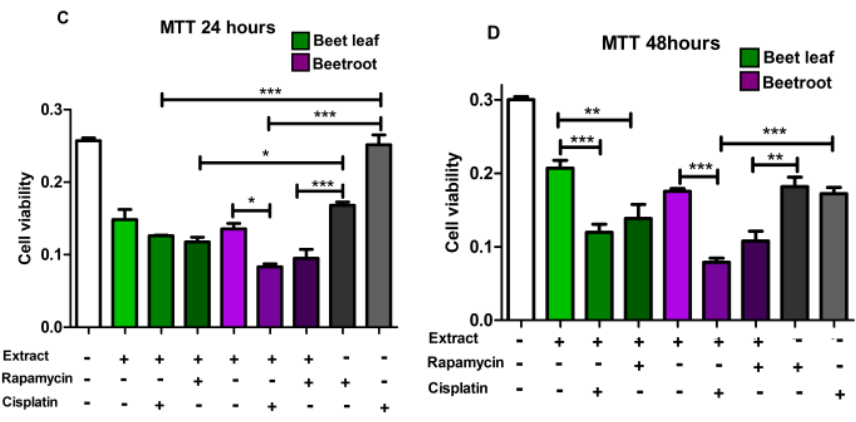

Figure 2. Analysis of colony formation $(n=3)$; the bars represent the mean \pm SEM. Means significantly different as shown by One-Way Anova, post test Multiple Comparisons vs. control ( $\left.{ }^{*} p<0,05 ;{ }^{* *} p<0,01 ;{ }^{* * *} p<0,001 ;{ }^{* * *} p<0001\right)$ in 10 days with a concentration of $1 \mathrm{ppm}$ and $10 \mathrm{ppm}$.
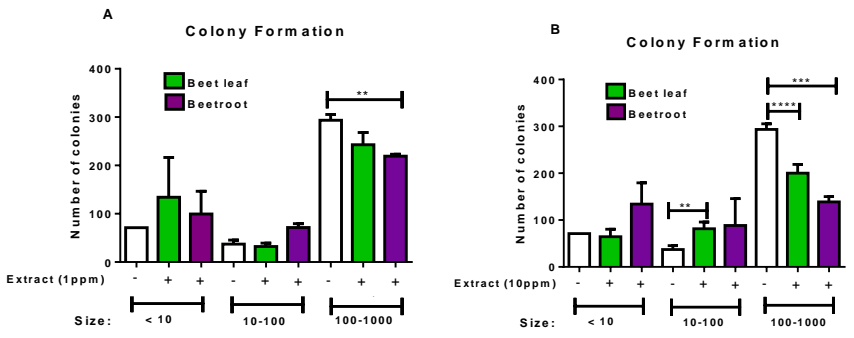

\section{Conclusions}

In the present study, it was observed a decrease in cell viability and colony formation in HeLa cells, demonstrating the effects of leaf and beet root extracts in colon cancer cells (HeLa).

\footnotetext{
1 ORGANIZAÇÃO PAN-AMERICANA DA SAÚDE DO BRASIL (OPAS) Folha informative - Câncer. Brasília: OPAS, 2018

2 INSTITUTO NACIONAL DE CÂNCER JOSÉ ALENCAR GOMES DA SILVA (INCA). Estimativa 2018: incidência de câncer no Brasil. Rio de Janeiro: INCA, 2017.

3 LEE et. al. Betalain and Betaine Composition of Greenhouse- or FieldProduced Beetroot (Beta vulgaris L.) and Inhibition of HepG2 Cell Proliferation. Journal of Agricultural and Food Chemistry. Vol. 62, n. 6, p. 1324-1331, fev., 2014. DOI: 10.1021/jf404648u.

4 ANTONINI et. al. Antiproliferative activity of vitexin-2-O-xyloside and avenanthramides on $\mathrm{CaCo}-2$ and $\mathrm{HepG} 2$ cancer cells occurs through apoptosis induction and reduction of pro-survival mechanisms. European Journal of Nutrition, vol. 57, n. 4, p. 1381-1395, June, 2018. DOI: 10.1007/s00394-0171418-y.
} 